\title{
Impact of Simulated Drought Stress on Soil Microbiology, and Nematofauna in a Native Shrub + Millet Intercropping System in Senegal
}

\author{
Sidy Diakhaté ${ }^{1,2,6 *}$, Ndeye-Yacine Badiane-Ndour ${ }^{1}$, Hassna Founoune-Mboup ${ }^{1}$, Sally Diatta ${ }^{1}$, \\ Abdoulaye Fofana Fall1', Rebacca R. Hernandez ${ }^{3}$, Laurent Cournac ${ }^{2}$, Richard Dick ${ }^{4}$, \\ Lydie Chapuis-Lardy 5
}

\author{
${ }^{1}$ National Research Laboratory for Crop Production (LNRPV/ISRA), Dakar, Senegal \\ ${ }^{2}$ LMI IESOL, International Laboratory for Ecological Intensification of Cultivated Soil in West Africa Dakar, Senegal \\ ${ }^{3}$ Land Air and Water Resource Department, University of California-Davis, Davis, CA, USA \\ ${ }^{4}$ School of Environment and Natural Resources, Ohio State University, Columbus, OH, USA \\ ${ }^{5}$ French National Research Institute for Sustainable Development (IRD), Montpellier, France \\ ${ }^{6}$ IRD-ISRA Research Center, BP1386, Dakar, Senegal \\ Email: *sidy.diakhate@ird.fr
}

How to cite this paper: Diakhaté, S., Badiane-Ndour, N.-Y., Founoune-Mboup, H., Diatta, S., Fall, A.F., Hernandez, R.R., Cournac, L., Dick, R. and Chapuis-Lardy, L. (2016) Impact of Simulated Drought Stress on Soil Microbiology, and Nematofauna in a Native Shrub + Millet Intercropping System in Senegal. Open Journal of Soil Science, 6, 189-203.

http://dx.doi.org/10.4236/ojss.2016.612018

Received: September 29, 2016

Accepted: December 3, 2016

Published: December 6, 2016

Copyright $\odot 2016$ by author(s) and Scientific Research Publishing Inc. This work is licensed under the Creative Commons Attribution International License (CC BY 4.0).

http://creativecommons.org/licenses/by/4.0/ (c) (i) Open Access

\begin{abstract}
Drought stress strongly affects soil biota and impairs crop production, which under climate change will be exacerbated in semi-arid cropping regions such as the Sahel. Hence soil management systems are needed that can buffer against drought. In West Africa, field studies have found intercropping of millet with the native shrub Piliostigma reticulatum improves soil-plant-water relations, microbial activity and diversity, and suppress parasitic nematodes, which can significantly increase crop yield. However, little information is available on its beneficial or negative effects on soils or crops during water stress. Therefore, the objective was to investigate the impact of $P$. reticulatum in moderating water stress effects on soil properties and pearl millet (Pennisetum glaucum [L.] R. Br.) productivity. In the greenhouse, soil chemical and microbial properties and millet growth were investigated with a factorial experiment of varying levels of soil moisture (favorable, moderately stressed, or severely stressed water conditions) that was imposed for 55 days on soils containing sole $P$. reticulatum or millet, or millet $+P$. reticulatum. The results showed that the presence of $P$. reticulatum did not buffer soils against water stress in relation to soil chemical and microbial properties measured at the end of the experiment. Severe water stress did significantly decrease the height, number of leaves, and aboveground biomass of millet plants. Additionally, respiration, nematofauna trophic structure and abundance decreased as water stress increased. Lastly, bacterial feeders and plant parasitic
\end{abstract}


nematodes were the most sensitive to severe water stress while fungal feeding nematodes remained unaffected. The results suggested that the intensity of water stress had more negative effects on soil basal respiration rather than soil microbial biomass.

\section{Keywords}

Sub-Saharan Africa, Shrub-Based Cropping System, Pennisetum glaucum (L.) R. Br., Water Stress, Climate Change, Nematode, Basal Respiration, Greenhouse Experiment

\section{Introduction}

Reducing climate change-related risks to food production in Sub-Saharan Africa (SSA), the most food-insecure region globally, will require adaptation and the management of stressors from global- to local-scales [1] [2]. Furthermore, for the Sahel, it must be addressed within a context of rural poverty and exploitation of natural resources.

At landscape levels, climatic drivers that affect crop production will be increased mean annual temperature and more erratic rainfall. For SSA, climate change will cause greater variability in water availability for agriculture [3]. At the same time, stressed agroecosystems are predicted to increase the damage from plant pathogens, ectoparasites, and diseases [4]. This presents a major challenge for the majority, subsistence SSA farmers who do not have the resources to purchase external inputs for fertilizers or control measures for diseases and pests.

The relationship between hunger-related deaths and drought throughout the latter half of the $21^{\text {st }}$ century across the Sahel, the semi-arid transition belt between the Saharan desert and the Sudanian savanna, are well documented [5]. Today, at least 120 million people still suffer from malnutrition in SSA [6]. Across SSA, pearl millet (Pennisetum glaucum [L.] R. Br.) is the sixth most important crop for food insecure among human populations [2]. Pearl millet is well adapted to drought and soils with poor inherent fertility, which are characteristic of SSA soils. Consequently, it is cultivated throughout the region for grain and fodder. In contrast to other crops (e.g., wheat, maize, rice), pearl millet has been understudied, which could diminish its adaptive capacity to climate change risks [2]. Pearl millet productivity is projected to decline by $10 \%$ within the Sahel and across Africa owing to changes in climate [7], compared to reported yield reductions for wheat and sorghum (17.2\% and $14.6 \%$, respectively). Adaptive capacity is further constrained by the nature of farming in SSA and pests: predominately small-scale and 98\% rainfed [3] [7] and the presence of plant- parasitic nematodes, specifically Helicotylenchus and Scutellonema (both Hoplolaimidae), recently reported as highly abundant in pearl millet fields [8].

Previous studies have demonstrated the link between climate and soil water content, which, in turn, controls microbial activity [9] [10], soil microbial community structure [11], and nematofauna [12]. Size and microbial activities include microbial biomass and soil basal respiration which can be affected negatively under water stress [13] espe- 
cially in SSA. Climate parameters can influence abiotic conditions, such as soil moisture availability that can influence biotic processes like decomposition [14]. Soil nematodes, which include several trophic groups and can be beneficial, innocuous or parasitic [15], are physiologically active only when water is available [16] making them good indicators of drought stress [12]. They indirectly modulate carbon and nitrogen cycling, in part, because they graze on plant roots and fungi and consume other edaphic biota [17]. Soil nematodes have been widely used for monitoring environmental change, and their responses play a key role in the feedbacks of terrestrial ecosystems to climate change because they are highly sensitive to changes in precipitation [18].

Drying and rewetting cycles represent a common physiological stress for the microbial communities and nematofauna inhabiting soil [19] [20], particularly soils of SSA due to the infrequency and variability of rainfall events and the warm [21]. Altered precipitation regimes, including drought, may create thresholds that alter nematofauna community composition. For example, bacterial feeding nematodes exhibit more sensitivity to drought than fungal feeding nematodes and drought conditions have been linked to a significant reduction in nematofauna abundance [12], resulting in altered trophic patterns, thus altered ecosystem functioning [10]. Understanding how water balance impacts soil biological communities and plant production is of paramount importance for future management and sustainability in a context of climate change.

Farmers in SSA have long practiced agroforestry, where woody tree species coexist with crops, which depending on the species can improve yields [22]. Agroforestry can reduce the vulnerability of agricultural production to climatic stress, in part, owing to improved soil quality, soil nutrient availability, and soil stabilization [23]. Across the SSA savannas most attention has focused on the parkland agrofortestry system where trees (e.g., Faidherbia albida, Parkia biglobosa, Vitellaria paradoxa) are planted or establish naturally in farmers' fields [24]. More recently, in the Sahel, two native woody shrubs, Guiera senegalensis JF Gmelin (Combretaceae) and Piliostigma reticulatum (DC.) Hochst. (Caesalpiniaceae) in particular, have been identified as "resource islands" that promote growth of groundnut (Arachis hypogaea [25]); mango (Mangifera indica) [26]; and pearl millet (Pennisetum glaucum [27]). These shrub-crop systems have greater potential to sequester carbon at field scales than manure or compost amendments or trees [28] and promote soil bacterial and fungal diversity and activity [28] [29] [30] [31] and significantly reduce plant feeding nematodes [8].

Thus, these shrub systems have potential to buffer the effects of water stress on soil biology and therefore could be an important management strategy for maintaining soils and crop productivity with future climate change. These systems are a local resource and do not require external purchased inputs and as such is a logical resource subsistence farmers of the Sahel could take advantage of. However, little information is available on whether soil from shrub intercropped systems moderate the effects of water stress on soil biology. Therefore, the objective of this study was to determine the impact of two levels of water stress on chemical and microbial properties, and nematode populations of soils that had been under long-term $P$. reticulatum intercropping or sole 
cropping in the absence of any woody species.

\section{Materials and Methods}

\subsection{Soil Sampling}

The sampling site is located in Nioro-du Rip, in the Kaolack region of the Peanut Basin in Senegal $\left(13^{\circ} 45 \mathrm{~N}, 15^{\circ} 47 \mathrm{~W} ; 18 \mathrm{~m}\right.$ above sea level). The two major crops cultivated in Nioro-du Rip are peanut (Arachis hypogaea L.) and pearl millet (Pennisetum glaucum (L.) R. Br.). The region is semi-arid with a north Sudanian climate (Köppen climate classification, BSh). Mean annual precipitation is $750 \mathrm{~mm}$, distributed from July to September. Mean air temperature ranges from $20^{\circ} \mathrm{C}$ from December to January and $35.7^{\circ} \mathrm{C}$ and from April to June [29]. The soil is a fine-sandy, mixed Haplic Ferric Lixisol [32], locally referred to as Deck-Dior [33]. The dominant native shrub species at the site is Piliostigma reticulatum (DC.) Hochst. (Caesalpinioideae), with stand of about 185 shrubs $\mathrm{ha}^{-1}$. Soil was collected (June $\left.20^{\text {th }} 2014\right)$ beneath the canopies $(0-20 \mathrm{~cm}$ depth) of $P$. reticulatum within a millet farmers and transferred into several individual bags and brought to Bel-Air Research Center for the greenhouse experiment. Soil was passed through a $2-\mathrm{mm}$ sieve and transferred immediately into $5.5 \mathrm{~L}$ plastic pots.

\subsection{Experimental Design}

The experiment was a completely randomized $4 \times 3$ factorial experiment ( 4 replications for each treatment) with 3 plant factors [control with no plant (C); sole P. reticulatum seedling (S); sole pearl millet (Mi); pearl millet plus $P$. reticulatum $(\mathrm{Mi}+\mathrm{S})]$ and 3 soil moisture levels [80\% water holding capacity (WHC), non-stressed (NSt); 40\% WHC, moderately stressed (MSt); 20\% WHC, severely stressed (SSt)].

Seven $\mathrm{kg}$ of soil was placed in each pot and had soil moisture adjusted to $60 \%$ WHC and pre-incubated in a greenhouse at $30^{\circ} \mathrm{C}\left( \pm 3^{\circ} \mathrm{C}\right)$ for one week. Twenty four $P$. reticulatum seeds were planted three months prior to starting the experiment and after which the seedlings were transplanted into $5.5 \mathrm{~L}$ plastic pots that had $7 \mathrm{~kg}$ of soil. After one week, the pots with $P$. reticulatum received three millet (Pennisetum glaucum (L.) R. $\mathrm{Br}$. Souna 3 cultivar) seeds. One week after the millet emerged, the millet plant nearest the shrub was allowed to remain and the other millet plants were removed. The water treatments were imposed by determining water content, gravimetrically, every 3 days. Soils and plants samples were collected in October 2014 when millet panicles were emerging in the $\mathrm{Mi}$ and $\mathrm{Mi}+\mathrm{S}$ pots.

\subsection{Plant Measurements}

The number of leaves and plant height $(\mathrm{cm})$ was measured at end of the experiment across all the treatments. Aboveground plant material was harvested at the soil surface, dried at $65^{\circ} \mathrm{C}$ for $48 \mathrm{~h}$, and then weighed. At the end of the experiment soil from each pot was homogenized and a portion set aside for air drying and analyzed for chemical properties, and another portion was kept moist in the plastic bags and stored at $4^{\circ} \mathrm{C}$ followed by biological assays as described below. 


\subsection{Soil Analyses}

Microbial biomass carbon was estimated by the fumigation-extraction method, using the gain in ninhydrin-reactive $\mathrm{N}$ after fumigation, multiplied by 21 [34]. Soil basal respiration ( $\mathrm{CO}_{2}$ evolution) was measured in $100 \mathrm{~cm}^{3}$ soil jars with $20 \mathrm{~g}$ fresh soil, using gas chromatography to measure the headspace $\mathrm{CO}_{2}$ concentration. The ratio between soil basal respiration and microbial biomass is known as the metabolic quotient $\left(\mathrm{qCO}_{2}\right)$. The metabolic quotient, $\mathrm{qCO}_{2}$, is used in this study as an indicator of soil rewetting and drying disturbance of soil biological functioning [35].

\subsection{Nematode Abundance and Trophic Groups Analysis}

For each sample, nematodes were extracted at the end of the experiment from approximately $250 \mathrm{~g}$ of wet soil using a modified Seinhorst method [36]. Collected nematodes were counted at $40 \times$ magnification using a dissecting microscope and preserved in a formaldehyde-glycerol mixture for identification to genus or family level at a higher magnification $(400 \times)$. Nematode was assigned to the different trophic group (Bacterial feeders, fungal feeders, plant feeders, Omnivores and Carnivores) according to their feeding habits [37].

\subsection{Statistical Analysis}

For each parameter (nematode trophic groups, plant parameters, basal respiration and metabolic quotient), we conducted a two-factor analysis of variance (ANOVA) and the means were compared using the Fisher test $(P<0.05)$. The variance was related to the main effects and to the interaction between shrub presence and soil water stress level. Means \pm SD were calculated, and the least significant difference (LSD) test of Fischer was used to compare our treatments using XLStat software. To evaluate relationships between water stress, soil nematode and microbial communities, we first ordinated a Redundancy Discriminatory Analysis (RDA) and an ordination bi-plot were used to discriminate the effects of treatments and using PC-Ord software. Statistical significance of water stress clustering for RDA ordination was done using a Permutational multivariate analysis of variance (PERMANOVA) [38]. This analysis was calculated using the abundances of different nematode trophic group (combined for the treatment), in PC-ORD Version V6.0 (MjM Software Design, Gleneden Beach, OR, USA). All PERMANOVA tests used Bray-Curtis dissimilarity; tests of significance were performed using 4999 unrestricted permutations.

\section{Results}

Effects of water stress and shrub association with millet on plant parameters.

In response to simulated drought stress, soil collected in pots with $20 \%$ of WHC significantly affected plant height, number of leaves, and dry aboveground biomass yield $(P<0.005$, Table 1 , Figure 1$)$ compared to the NSt $(80 \%$ of WHC). There was a significant soil treatment $\mathrm{x}$ water stress interaction only for number of leaves (Table 1). Simulated drought stress corresponded to decreased plant height and aboveground bio- 
mass for $\mathrm{Mi}$ and $\mathrm{Mi}+\mathrm{S}$, and these effects were more pronounced under severely stressed conditions (Figure 1). Intercropping millet with shrub $(\mathrm{Mi}+\mathrm{S})$ had no positive effect on millet growth or tolerance to stress.

\section{Response of total nematode abundance to soil moisture conditions.}

Total nematode abundance was negatively affected by both moderate and severe drought stress $(P<0.0001$, Table 1 and Table 2$)$. The highest nematode abundance (1277 individuals $100 \mathrm{~g}^{-1}$ soil in $\mathrm{Mi}+\mathrm{S}$ treatment) was observed in the NSt, lowest nematode abundance was recorded in severely stressed treatment (473 individuals $100 \mathrm{~g}^{-1}$ soil; Figure 2). Total abundance was also affected by soil treatment type (Table 2). Mi $+\mathrm{S}$ treatment NSt conditions of water had the highest nematode populations; however this abundance was significantly reduced in the MSt and SSt treatments (Figure 2).

\section{Responses of nematode trophic groups to soil moisture conditions}

Free-living nematodes (bacterial feeders, fungal feeders, omnivores and carnivores) were the most dominant observed trophic group at 59\% across all plants and water treatments. Also across all treatments, bacterial feeding nematodes (38\%) were more abundant than fungal feeding nematodes (12\%). The relative abundance of all trophic groups were influenced by level of water treatment $(P<0.05$; Table 2$)$, except for plant feeding nematodes. Bacterial, plant, and omnivorous feeding nematodes were significantly affected by water stress $(P<0.05$; Table 2$)$ and the abundance of these groups were negatively correlated with the SSt treatment (Figure 1). Carnivorous and omnivorous nematodes were in low abundance $<40$ individuals $100 \mathrm{~g}^{-1}$ dry soil but none-

Table 1. Effect of varying levels of water availability on $P$. glaucum plant height, number of leaves, and aboveground biomass across four soil plant treatments of sole millet or $P$. reticulatum or millet $+P$. reticulatum.

\begin{tabular}{ccccc}
\hline Factors & Df & Plant Height & Number of leaves & Aboveground biomass \\
\hline Water level & 2 & $<0.0001$ & 0.003 & $<0.0001$ \\
Plants & 3 & 0.002 & 0.013 & 0.083 \\
Water ${ }^{*}$ Plants & 2 & 0.729 & 0.000 & 0.145 \\
\hline
\end{tabular}

Table 2. Effect of water stress treatments on soil nematode microbial, communities and metabolic quotient.

\begin{tabular}{|c|c|c|c|c|c|c|c|c|c|}
\hline \multirow{3}{*}{ Factors } & \multirow{3}{*}{ Df } & \multicolumn{6}{|c|}{ Nematodes } & \multirow[b]{3}{*}{ Basal respiration } & \multirow[b]{3}{*}{$\mathrm{qCO}_{2}$} \\
\hline & & \multirow{2}{*}{$\begin{array}{c}\text { All } \\
\text { nematodes }\end{array}$} & \multicolumn{5}{|c|}{ Trophic groups } & & \\
\hline & & & $\mathrm{Bac}$ & Fong & Phyto & Om & Car & & \\
\hline Water level & 2 & $<0.0001$ & $<0.0001$ & 0.008 & $<0.0001$ & 0.005 & 0.008 & $<0.0001$ & 0.007 \\
\hline Plant & 3 & $<0.0001$ & 0.002 & $<0.0001$ & 0.077 & 0.000 & 0.524 & 0.0246 & $<0.0001$ \\
\hline Water $*$ Plant & 6 & $<0.0001$ & 0.001 & $<0.0001$ & 0.344 & 0.387 & 0.007 & 0.0113 & 0.001 \\
\hline
\end{tabular}



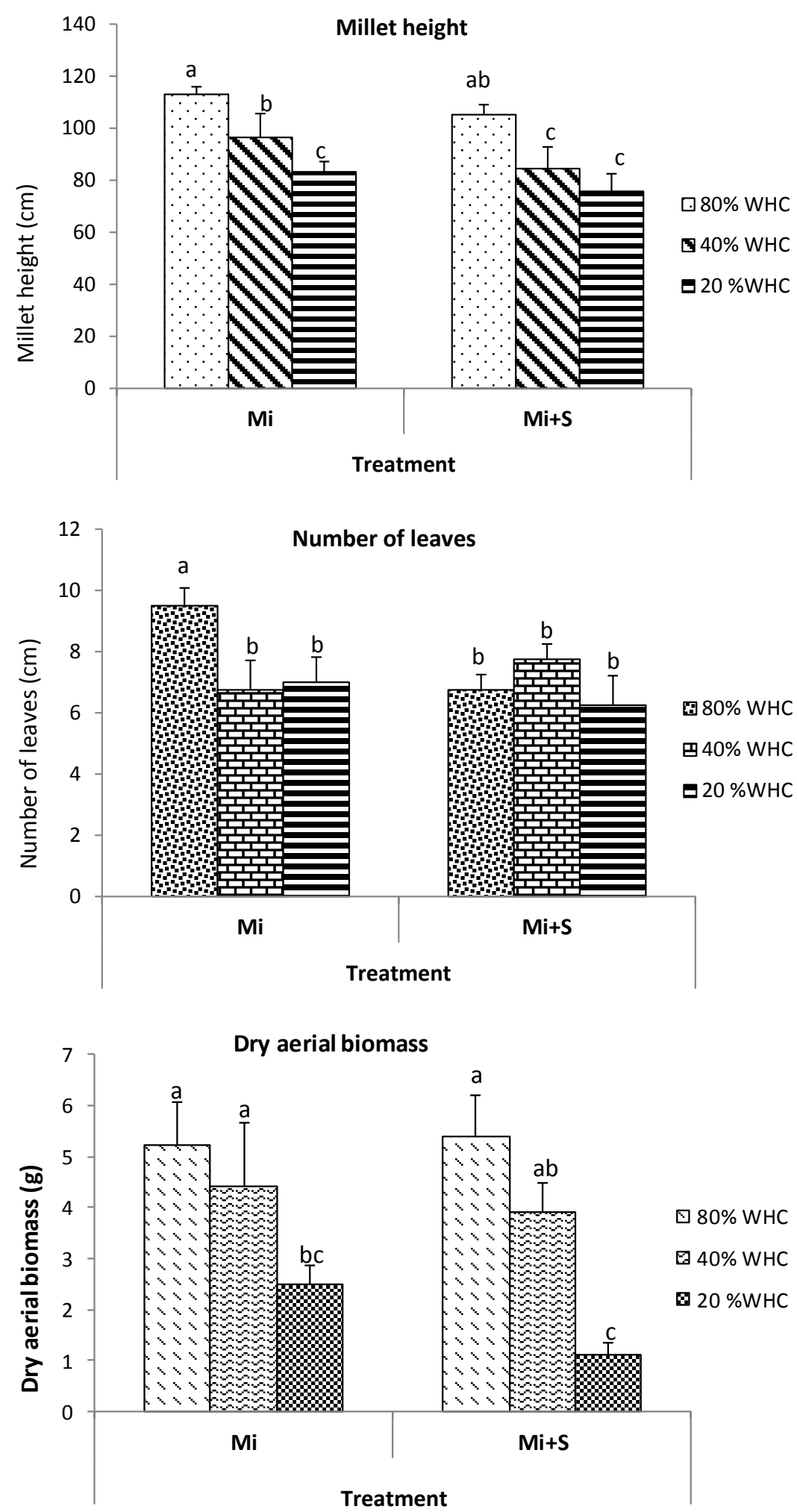

Figure 1. Response of millet growth parameters (height, number of leaves, dry aboveground biomass) to simulated drought stress and soil treatments: (i) millet alone ("M") and (ii) millet intercropped with $P$. reticulatum (“ $\mathrm{M}+\mathrm{S}$ ”). Letters denote significant differences among treatment means (Fishers's test, $P<0.05$ ). 


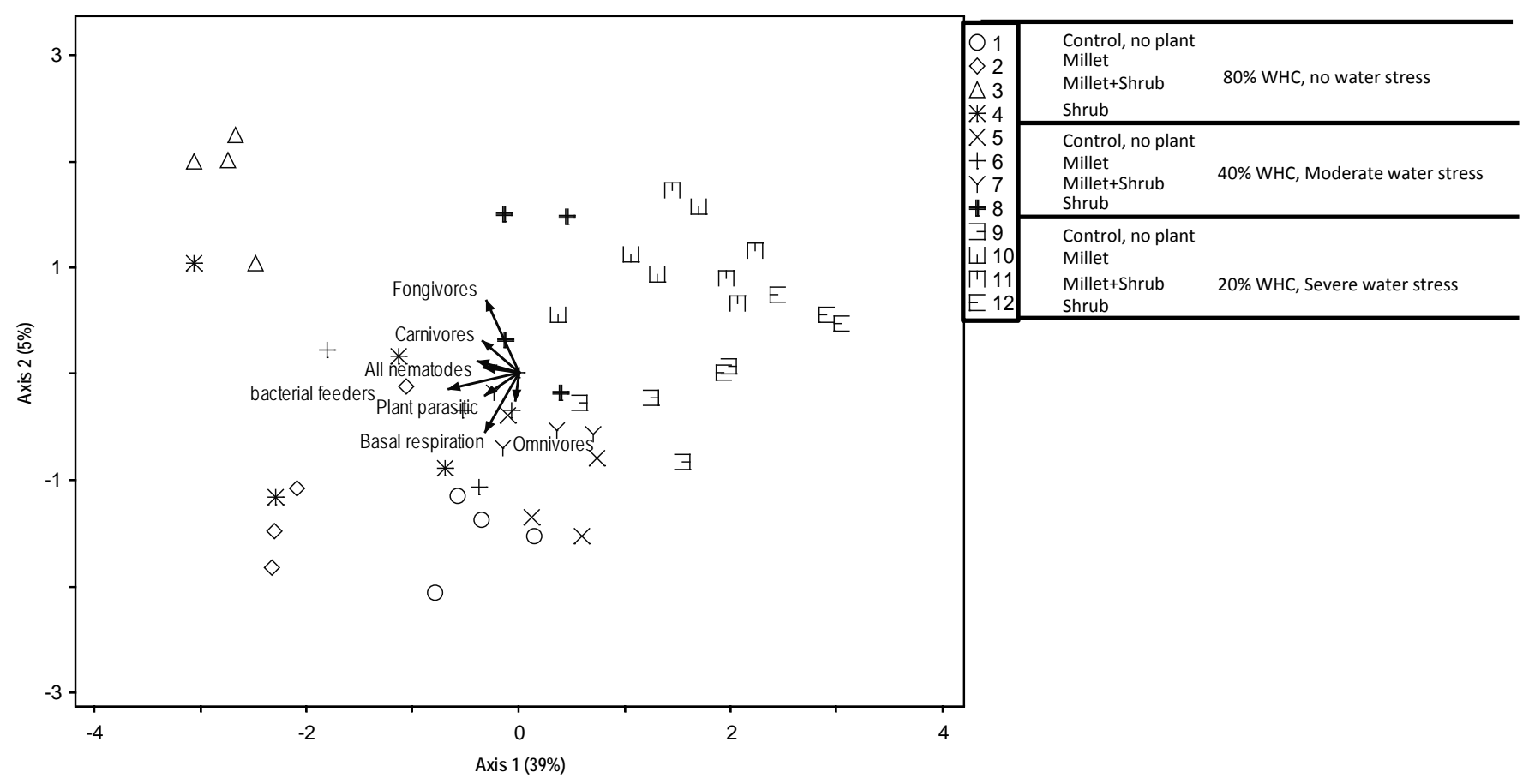

Figure 2. Two axis diagram of RDA ordination of the investigated soil samples, showing weights and orientation of samples and soil variables, i.e. nematode abundance, soil basal respiration (total and by trophic groups) and dry aboveground biomass of plants grown in the pot experiment.

the-less did show significant effects due to shrub intercropping (Table 2). Total abundance of bacterial feeding nematodes (120 individuals $100 \mathrm{~g}^{-1}$ dry soil) in the NSt treatment was significantly reduced to 96 individuals $100 \mathrm{~g}^{-1}$ dry soil in SSt treatment. The moderate or severely water stressed treatments for fungal feeding nematodes were not significantly different than the control.

\section{Soil basal respiration, metabolic quotient and microbial biomass.}

The results showed that after 55-days, the various water stress treatments all had significant effects on soil basal respiration $(P<0.0001$; Table 2$)$ regardless of plant management treatments. The basal respiration $\mathrm{n}$ SSt treatment was much lower than the NSt treatment at 3.25 and $5.60 \mu \mathrm{g} \mathrm{C}-\mathrm{CO}_{2} \mathrm{~g}^{-1}$ dry soil $\mathrm{h}^{-1}$, respectively. Under SSt, the Mi $+\mathrm{S}$ and Mi treatments were not significantly different than $\mathrm{C}$ treatment for basal respiration.

$\mathrm{qCO}_{2}$ ranged from 0.062 to $0.180 \mu \mathrm{g} C-\mathrm{CO}_{2} \mu \mathrm{g}^{-1} \mathrm{C}_{\mathrm{mic}} \mathrm{h}^{-1}$ and was significantly affected by the shrub and water stress treatments $(P<0.05$; Table 2$) . \mathrm{qCO}_{2}$ was highest in the NSt treatment, regardless of the planting treatment. In contrast, the SSt treatment had the lowest $\mathrm{qCO}_{2}$ values.

Eigenvalues derived from RDA showed that first axis explained 39\% of the total variance and the second axis 5\% (Figure 2) and that water stress was discriminated along axis one. There were significant differences between groups corresponding to the three (3) level of WHC based on RDA plots using PermAnova Analysis (Table 3). All variables (nematodes trophic groups, soil basal respiration, plant biomass) in this study 
Table 3. PerManova on bray-curtis distances for evaluation of differences in variables between groups in RDA ordination.

\begin{tabular}{cccccc}
\hline Source & d.f. & SS & MS & F & p \\
\hline Sym & 11 & 0.79702 & 0.72 & 42.311 & 0.0002 \\
Residual & 36 & 0.061 & 0.002 & \\
Total & 47 & 0.85867 & & \\
\multicolumn{5}{c}{ Pairwise comparisons of the significant difference } \\
between group according to the water stress treatment \\
\hline Level of stress & $\mathrm{t}$ & $\mathrm{p}$ & \\
NS vs. MS & 5.352 & 0.0002 & \\
NS vs. SS & 6.364 & 0.0002 & \\
MS vs. SS & 1.954 & 0.0326 & \\
& Randomization test of significance of pseudo F value \\
\end{tabular}

were negatively correlated with the SSt treatment indicating that soil metabolic activity and nematode trophic diversity were negatively correlated with the SSt treatment.

\section{Discussion}

\section{Effects of water stress and shrub association on millet dry matter yield}

All plant morphological measurements responded negatively to severe drought stress, especially when millet was grown at $20 \%$ of WHC. Similar results were reported by others [39] [40]. Drought-induced stress has been linked to the modification of plant physiological traits, which in turn affects morphological parameters [41]. For example, water stress causes interruption of water flow from the xylem to the surrounding elongating cells, which in turn reduces plant height [42].

Drought stress reduced aboveground dry matter and produced smaller leaves that reduced light interception [43] thus affecting photosynthesis. In our greenhouse experiment there was no positive millet response to shrub intercropping shrub in contrast to what has been previously reported in field studies [8] [25] [44].

A major difference was that under field conditions shrubs perform hydraulic lift [45] which is the movement of water along a water potential gradient that is high in the subsoil and low in the surface. This happens at night when stomata close and water moves up through tap roots and is released to surrounding soil by surface roots. Indirect evidence from the study by [25], suggests that shrubs can assist crops through drought periods and [45] showed that under field conditions, there is no negative competition for water between shrubs and crops which in part was due to these two types of plants having roots in different layers of the soil. Obviously, in the current study using pots, hydraulic lift was not a factor and the roots of both shrubs and millet were exploring the same soil. So in fact these two factors as expressed in our experimental design, a situation for water competition between millet and shrubs occurred.

Effects of water stress and shrub association on soil basal respiration

Basal respiration decreased with SSt treatment, yet microbial biomass was unaffected. However in MSt soils, basal respiration was not significantly different than NSt treat- 
ment. This may be related to the fact that soil fauna inhabiting tropical sandy soil, which are frequently exposed to drought conditions in their natural environment, are already adapted to this stress. Kaiserman et al. [20] reported that moderate droughts had no effect on overall $\mathrm{CO}_{2}$ emissions but severe droughts led to a lower loss of soil $\mathrm{C}$ due to the absence of mineralization during the longer periods of desiccation. Microorganisms are crucial components of the soil $\mathrm{C}$ cycle as they mineralize soil organic matter providing nutrients for plant growth and crop productivity. When subjected to water stress, soil microorganisms initiate physiological responses that shift resource allocation, potentially altering the flow of $\mathrm{C}$ and $\mathrm{N}$ [9], and thus negatively affecting millet productivity. The results demonstrated that MSt soil treatments were not significantly different in terms of soil basal respiration and microbial biomass compared to the NSt treatments. This is consistent with other studies of semi-arid ecosystems that have shown microbial behavioral and physiological adaptations to water stress [46].

The metabolic quotient $\left(\mathrm{qCO}_{2}\right)$ has been proposed as an index of microbial disturbance and stress [47]. This indicator initially had high values for the non-stressed control but then tended to decrease for all treatments-particularly for the severely stressed treatment. However, there were no significant differences due to the crop effect or water stress treatments. The overall decreasing trend in $\mathrm{qCO}_{2}$ across all treatments may reflect the general soil disturbance [48].

\section{Effects of water stress and millet-shrub association on nematode community}

The results indicate that nematofauna were very sensitive to water stress irrespective of shrub presence (Figure 3 ). There were significant changes in the total nematode abundance after 55 days due to various water stress treatments. However, nematode ab-

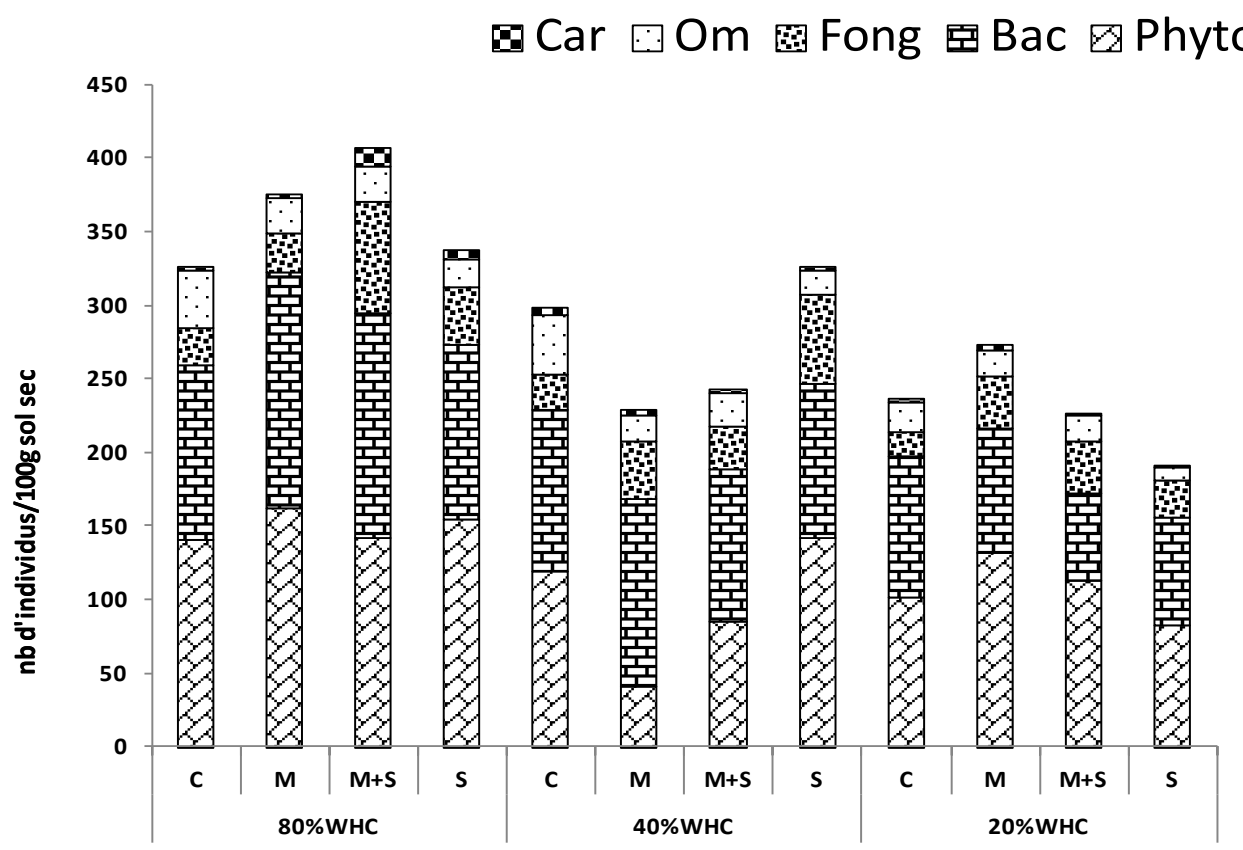

Figure 3. Response of bacterial-feeders, fungal-feeders, omnivores, carnivores and plant-parasites to shrub association and water stress. 
undance in NSt treatment were very similar to what Diakhaté et al. [8] reported from samples taken in the field at the same site where soils were retrieved for the pot experiment. When soil was submitted to water stress, nematode population density was significantly reduced (Figure 3 ) which shows the sensitivity of nematodes to water levels [12] [18] [49].

Evaluation of trophic levels of nematodes, the data showed that the dominant nematode trophic groups in the intercropping system were bacterial feeding and plant feeding nematodes. These results could be explained by the fact that bacterial feeding nematodes are the most abundant soil nematodes and were positively correlated with water availability [50]. This result is in line with [12] who found a high sensitivity of bacterial-feeding nematodes to drought. In contrast, plant feeding nematode abundance corresponds to the presence of the millet roots as sole millet or millet plus shrub. The results previous reports that soil nematodes are sensitive to environmental disturbance and water stress [51] [52].

\section{Conclusion}

In summary, the results represent a contribution to the understanding of soil microbial community response in terms of adaptation of microbial biomass, shifts in nematode trophic groups and the negative impact on millet production in the context of imposed water stress. Climate change effects, such as severe drought, may impact microbial respiration such as microbial quotient rather than the abundance of microorganisms and led to decreases in nematode abundance (e.g., drought intolerant bacterivores). Our study highlighted water stress thresholds beyond which a decrease in microbial activity and nematode abundance can be observed. More work is needed to elucidate the physiology and ecology of microorganisms and nematode relationships on nutrient cycling in soil food webs in response to climatic change, especially in areas with arid climate regimes.

\section{Acknowledgements}

We thank Moustapha Sané for soil analysis, Roger Bayala for help in the field, Alpha Oumar Ba and Djibril Djigal for Nematodes analysis. This work was funded by the by the USAID PEER Program under grant agreement: \#AID-OAA-A-11-00012 in collaboration with the US National Science Foundation.

\section{References}

[1] Schmidhuber, J. and Tubiello, F.N. (2007) Global Food Security under Climate Change. Proceedings of the National Academies of Sciences of the United States of America, 104, 19703-19708. https://doi.org/10.1073/pnas.0701976104

[2] Lobell, D.B., Burke, M.B., Tebaldi, C., Mastrandrea, M.D., Falcon, W.P. and Naylor, R.L. (2008) Prioritizing Climate Change Adaptation Needs for Food Security in 2030. Science, 319, 607-610. https://doi.org/10.1126/science.1152339

[3] Niang, I., Ruppel, O.C., Abdrabo, M.A., Essel, A., Lennard, C., Padgham, J. and Urquhart, P. (2014) Chapter 22: Africa. In: Barros, V.R., Field, C.B., Dokken, D.J., Mastrandrea, M.D., 
Mach, K.J., Bilir, T.E., Chatterjee, K.L., Ebi, K.L., Estrada, Y.O., Genova, R.C., Girma, B., Kissel, E.S., Levy, A.N., MacCracken, S., Mastrandrea, P.R. and White, L.L., Eds., Climate Change 2014: Impacts, Adaptation, and Vulnerability. Part B: Regional Aspects. Contribution of Working Group II to the Fifth Assessment of the Intergovernmental Panel on Climate Change, Cambridge University Press, Cambridge and New York, 1199-1265.

[4] Coakley, S.M., Scherm, H. and Chakraborty, S. (1999) Climate Change and Plant Disease Management. Annual Review of Phytopathology, 37, 399-426.

https://doi.org/10.1146/annurev.phyto.37.1.399

[5] Battisti, D.S. and Naylor, R.L. (2009) Historical Warnings of Future Food Insecurity with Unprecedented Seasonal Heat. Science, 323, 240-244. https://doi.org/10.1126/science.1164363

[6] Liu, J., Fritz, S., van Wesenbeeck, C.F.A., Fuchs, M., You, L., Obersteiner, M. and Yang, H. (2008) A Spatially Explicit Assessment of Current and Future Hotspots of Hunger in Sub-Saharan Africa in the Context of Global Change. Global and Planetary Change, 64, 222-235. https://doi.org/10.1016/j.gloplacha.2008.09.007

[7] Knox, J., Hess, T., Daccache, A. and Wheeler, T. (2012) Climate Change Impacts on Crop Productivity in Africa and South Asian Environmental Research. Letters, 7, 34-32.

[8] Diakhaté, S., Villenave, C., Diallo, N.H., Ba, A.O., Djigal, D., Masse, D., et al. (2013) The Influence of a Shrub-Based Intercropping System on the Soil Nematofauna When Growing Millet in Senegal. European Journal of Soil Biology, 57, 35-41. https://doi.org/10.1016/j.ejsobi.2013.04.003

[9] Schimel, J., Balser, T.C. and Wallenstein, M. (2007) Microbial Stress-Response Physiology and Its Implications for Ecosystem Function. Ecology, 88, 1386-1394.

https://doi.org/10.1890/06-0219

[10] Sylvain, Z.A., Wall, D.H., Cherwin, K.L., Peters, D.P.C., Reichmann, L.G. and Sala, O.E. (2014) Soil Animal Responses to Moisture Availability Are Largely Scale, Not Ecosystem Dependent: Insight from a Cross-Site Study. Global Change Biology, 20, 2631-2643. https://doi.org/10.1111/gcb.12522

[11] Holland, T.C., Reynolds, A.G., Bowen, P.A., Bogdanoff, C.P., Marciniak, M., Brown, R.B. and Hart, M.M. (2013) The Response of Soil Biota to Water Availability in Vineyards. Pedobiologia, 56, 9-14. https://doi.org/10.1016/j.pedobi.2012.08.004

[12] Landesman, W.J., Treonis, A.M. and Dighton, J. (2011) Effects of a One-Year Rainfall Manipulation on Soil Nematode Abundances and Community Composition. Pedobiologia, 54, 87-91. https://doi.org/10.1016/j.pedobi.2010.10.002

[13] Hueso, S., Garcia, C. and Hernandez, T. (2012) Severe Drought Conditions Modify the Microbial Community Structure, Size and Activity in Amended and Unamended Soils. Soil Biology and Biochemistry, 50, 167-173. https://doi.org/10.1016/j.soilbio.2012.03.026

[14] Singh, B.P., Hatton, B.J., Singh, B., Cowie, A.L. and Kathuria, A. (2010) Influence of Biochars on Nitrous Oxide Emission and Nitrogen Leaching from Two Contrasting Soils. Journal of Environmental Quality, 39, 1224-1235. https://doi.org/10.2134/jeq2009.0138

[15] Ferris, H. (2010) Contribution of Nematodes to the Structure and Function of the Soil Food Web. Journal of Nematology, 42, 63-67.

[16] Bardgett, R. (2005) The Biology of Soil: A Community and Ecosystem Approach. Oxford University Press, Oxford. https://doi.org/10.1093/acprof:oso/9780198525035.001.0001

[17] Ferris, H. and Bongers, T. (2006) Nematode Indicators of Organic Enrichment. Journal of Nematology, 38, 3-12.

[18] Sun, X., Zhang, X., Zhang, S., Dai, G., Han, S. and Liang, W. (2013) Soil Nematode Res- 
ponses to Increases in Nitrogen Deposition and Precipitation in a Temperate Forest. PLoS ONE, 8, e82468. https://doi.org/10.1371/journal.pone.0082468

[19] Fierer, N., Schimel, J.P. and Holden, P.A. (2003) Influence of Drying-Rewetting Frequency on Soil Bacterial Community Structure. Microbial Ecology, 45, 63-71.

https://doi.org/10.1007/s00248-002-1007-2

[20] Kaizermann, A., Maron, P.A., Beaumelle, L. and Lata, J.C. (2015) Fungal Communities Are More Sensitive Indicators to Non-Extreme Soil Moisture Variations than Bacterial Communities. Applied Soil Ecology, 86, 158-164. https://doi.org/10.1016/j.apsoil.2014.10.009

[21] Nicholson, S.E. (2012) The West African Sahel: A Review of Recent Studies on the Rainfall Regime and Its Interannual Variability. ISRN Meteorology, 2013, Article ID: 453521.

[22] Lasco, R.D., Delfino, R.J.P., Catacutan, D.C., Simelton, E.S. and Wilson, D.M. (2014) Climate Risk Adaptation by Smallholder Farmers: The Roles of Trees and Agroforestry. Current Opinion in Environmental Sustainability, 6, 83-88. https://doi.org/10.1016/j.cosust.2013.11.013

[23] Buresh, R.J. and Tian, G. (1998) Soil Improvement by Trees in Sub-Saharan Africa. In: Nair, P.K.R. and Latt, C.R., Eds., Directions in Tropical Agroforestry Research, Vol. 53, Springer Netherlands, Berlin, 51-76. https://doi.org/10.1007/978-94-015-9008-2 2

[24] Boffa, J.M. (2000) Les parcs Agroforetiers en Afrique SubSaharienne. Cahier FAO Conservation 34 .

[25] Dossa, E.L., Diedhiou, I., Khouma, M., Sene, M., Badiane, A.N., Samba, S.A.N., Assigbetse, K.B., Sall, S., Lufafa, A., Kizito, F., Dick, R.P. and Saxena, J. (2013) Crop Productivity and Nutrient Dynamics in a Shrub-Based Farming System of the Sahel. Agronomy Journal, 105, 1237-1246. https://doi.org/10.2134/agronj2012.0432

[26] Hernandez, R., Debenport, S.J., Leewis, M.-C., Ndoye, F., Nkenmogne, I.E., Soumare, A., Thuita, M., Gueye, M., Miambi, E., Chapuis-Lardy, L., Diedhiou, I. and Dick, R.P. (2015) The Native Shrub, Pilostigma reticulatum, as an Ecological "Resource Island" for Mango Trees in the Sahel. Agriculture, Ecosystems \& Environment, 204, 51-61.

https://doi.org/10.1016/j.agee.2015.02.009

[27] Debenport, S.J., Assigbetse, K., Bayala, R., Chapuis-Lardy, L., Dick, R.P. and Gardener, B.B.M. (2015) Association of Shifting Populations in the Root Zone Microbiome of Millet with Enhanced Crop Productivity in the Sahel Region (Africa). Applied Environmental Microbiology, 81, 2841-2851. https://doi.org/10.1128/AEM.04122-14

[28] Lufafa, A., Diédhiou, I., Samba, S.A.N., Séne, M., Khouma, M., Kizito, F., Dick, R.P., Dossa, E. and Noller, J.S. (2008) Carbon Stocks and Patterns in Native Shrub Communities of Senegal's Peanut Basin. Geoderma, 146, 75-82.

https://doi.org/10.1016/j.geoderma.2008.05.024

[29] Diedhiou, S., Badiane, A.N., Diedhiou, I., Khoum, M., Samba, A.N.S., Sène, M. and Dick, R.P. (2009) Succession of Soil Microbial Communities during Decomposition of Native Shrub Litter of Semi-Arid Senegal. Pedobiologia, 52, 273-286.

[30] Diedhiou-Sall, S., Dossa, E.L., Diedhiou, I., Badiane, A.N., Assigbetsee, K.B., Ndiaye, N.A.S., Khouma, M., Sène, M. and Dick, R.P. (2013) Microbiology and Macrofaunal Activity in Soil beneath Shrub Canopies during Residue Decomposition in Agroecosystems of the Sahel. Soil Science Society of America Journal, 77, 501-551. https://doi.org/10.2136/sssaj2012.0284

[31] Diakhaté, S., Gueye, M., Chevallier, T., Diallo, N.H., Assigbetse, K., Abadie, J., Diouf, M., Masse, D., Sembene, P.M., Ndour, Y.B., Dick, R.P. and Chapuis-Lardy, L. (2016) Soil Microbial Functional Capacity and Diversity in a Millet-Shrub Intercropping System of 
Semi-Arid Senegal. Journal of Arid Environments, 129, 71-79.

https://doi.org/10.1016/j.jaridenv.2016.01.010

[32] FAO, Food and Agriculture Organization (2006) World Reference Base for Soil Resources: A Framework for International Classification, Correlation and Communication. World Soil Resources Reports 103, FAO, Rome.

[33] Badiane, A.N., Khouma, M. and Sene, M. (2000) Région de Diourbel: Gestion des sols. Drylands Res. Work. Pap. 15, Somerset, UK.

[34] Amato, M. and Ladd, J.N. (1988) Assay for Microbial Biomass Based on Ninhydrin-Reactive Nitrogen Extracts from Fumigated Soil. Soil Biology \& Biochemistry, 20, 107-114. https://doi.org/10.1016/0038-0717(88)90134-4

[35] West, A.W., Sparling, G.P. and Speir, T.W. (1989) Microbial Activity in Gradually Dried or Rewetted Soils as Governed by Water and Substrate Availability. Australian Journal of Soil Research, 27, 747-757. https://doi.org/10.1071/SR9890747

[36] Seinhorst, J.W. (1962) Extraction Methods for Nematodes Inhabiting Soil. In: Murphy, P.W., Ed., Progress in Soil Zoology, Butterworths, London, 243-256.

[37] Yeates, G.W., Bongers, T., de Goede, R.G.M., Freckman, D.W. and Georgieva, S.S. (1993) Feeding Habits in Nematode Families and Genera-An Outline for Soil Ecologists. Journal of Nematology, 25, 315-331.

[38] Anderson, M.J., Gorley, R.N. and Clarke, R.K. (2005) Permanova Permutational Multivariate Analysis of Variance, a Computer Program. Vol. 24, University of Auckland, Auckland.

[39] Anjum, S.A., Xie, X., Wang, L., Saleem, M.F., Man, C. and Lei, W. (2011) Morphological, Physiological and Biochemical Responses of Plants to Drought Stress. African Journal of Agricultural Research, 6, 2026-2032.

[40] Ndiaye, M., Cavalli, E., Manga, A.G.B. and Diop, T.A. (2011) Improved Acacia senegal Growth after Inoculation with Arbuscular Mycorrhizal Fungi under Water Deficiency Conditions. International Journal of Agriculture \& Biology, 13, 271-274.

[41] Suzuki, N., Rivero, R.M., Shulaev, V., Blumwald, E. and Mittler, R. (2014) Abiotic and Biotic Stress Combinations. New Phytologist, 203, 32-43. https://doi.org/10.1111/nph.12797

[42] Randhawa, N., Kaur, J., Singh, S. and Singh, I. (2014) Growth and Yield in Chikpea (Cicer arietinum L.) Genotypes in Response to Water Stress. African Journal of Agricultural Research, 9, 982-992. https://doi.org/10.5897/AJAR2013.7671

[43] Nam, N.H., Subbaroa, G.V., Chauhan, Y.S. and Johansen, C. (1998) Importance of Canopy Attributes in Determining Dry Matter Accumulation of Pigeonpea under Contrasting Moisture Regimes. Crop Science, 38, 955-961. https://doi.org/10.2135/cropsci1998.0011183X003800040013x

[44] Kizito, F., Sene, M., Draglia, M., Lufafa, A., Diedhiou, I., Dossa, E., Cuenca, R., Selker, J.S. and Dick, R.P. (2007) Soil Water Balance of Annual Crop-Native Shrub Systems in Senegal's Peannut Basin: The Missing Link. Agricultural Water Management, 90, 137-148. https://doi.org/10.1016/j.agwat.2007.02.015

[45] Kizito, F., Dragila, M.I., Senè, M., Brooks, R.J., Meinzer, F.C., Diedhiou, I., Diouf, M., Lufafa, A., Dick, R.P., Selker, J. and Cuenca, R.H. (2012) Hydraulic Redistribution by Two Semi-Arid Shrub Species: Implications for Sahelian Agro-Ecosystems. Journal of Arid Environments, 83, 69-77. https://doi.org/10.1016/j.jaridenv.2012.03.010

[46] Berg, N. and Steinberger, Y. (2010) Are Biological Effects of Desert Shrubs More Important than Physical Effects on Soil Microorganisms? Microbial Ecology, 59, 121-129. https://doi.org/10.1007/s00248-009-9599-4 
[47] Wardle, D.A. and Ghani, A. (1995) A Critique of the Microbial Metabolic Quotient $\left(q \mathrm{CO}_{2}\right)$ as a Bioindicator of Disturbance and Ecosystem Development. Soil Biology \& Biochemistry, 27, 1601-1610. https://doi.org/10.1016/0038-0717(95)00093-T

[48] Anderson, T.H. and Domsch, K.H. (1990) Application of Eco-Physiological Quotients ( $q \mathrm{CO}_{2}$ and $q \mathrm{D}$ ) on Microbial Biomasses from Soils of Different Cropping Histories. Soil Biology \& Biochemistry, 22, 251-255. https://doi.org/10.1016/0038-0717(90)90094-G

[49] Bakonyi, G. and Nagy, P. (2000) Temperature- and Moisture-Induced Changes in the Structure of the Nematode Fauna of a Semiarid Grassland-Patterns and Mechanisms. Global Change Biology, 6, 697-707. https://doi.org/10.1046/j.1365-2486.2000.00354.x

[50] Briar, S.S., Fonte, S.J., Park, I., Six, J., Scow, K. and Ferris, H. (2011) The Distribution of Nematodes and Soil Microbial Communities across Soil Aggregate Fractions and Farm Management Systems. Soil Biology \& Biochemistry, 43, 905-914. https://doi.org/10.1016/j.soilbio.2010.12.017

[51] Eisenhauer, N., Reich, P.B. and Scheu, S. (2012) Increasing Plant Diversity Effects on Productivity with Time due to Delayed Soil Biota Effects on Plants. Basic and Applied Ecology, 13, 571-578. https://doi.org/10.1016/j.baae.2012.09.002

[52] Klass, J.R., Peters, D.P., Trojan, J.M. and Thomas, S.H. (2012) Nematodes as an Indicator of Plant-Soil Interactions Associated with Desertification. Applied Soil Ecology, 58, 66-77. https://doi.org/10.1016/j.apsoil.2012.03.005

\section{Submit or recommend next manuscript to SCIRP and we will provide best service for you:}

Accepting pre-submission inquiries through Email, Facebook, LinkedIn, Twitter, etc. A wide selection of journals (inclusive of 9 subjects, more than 200 journals)

Providing 24-hour high-quality service

User-friendly online submission system

Fair and swift peer-review system

Efficient typesetting and proofreading procedure

Display of the result of downloads and visits, as well as the number of cited articles

Maximum dissemination of your research work

Submit your manuscript at: http://papersubmission.scirp.org/

Or contact ojss@scirp.org 